\title{
IL-8 and neutrophil elastase levels in the respiratory tract of infants with RSV bronchiolitis
}

\author{
M. Abu-Harb*, F. Bell*, A. Finn*, W.H. Rao*, L. Nixon+, D. Shale ${ }^{+}$, M.L. Everard*
}

\begin{abstract}
IL-8 and neutrophil elastase levels in the respiratory tract of infants with RSV bronchiolitis. M. Abu-Harb, F. Bell, A. Finn, W.H. Rao, L. Nixon, D. Shale, M.L. Everard. (C)ERS Journals Ltd 1999.
\end{abstract}

ABSTRACT: The aim of this study was to determine whether interleukin (IL)-8 is released within the upper respiratory tract of infants during respiratory syncytial virus (RSV) bronchiolitis and whether the large number of polymorphonuclear neutrophils (PMNs) present in the respiratory tract of these infants are contributing to the inflammation through release of inflammatory mediators.

Twenty-seven infants with acute bronchiolitis were recruited during one winter epidemic and 20 infant control subjects were recruited from a cohort participating in a community-based vaccine study. Samples of airways fluid were obtained using nasal lavage. The lavage fluid was spun to remove the cells, and the supernatant was stored at $-\mathbf{7 0}^{\circ} \mathrm{C}$. The supernatants were subsequently assayed for the presence of IL-8, total human neutrophil elastase (HNE) and neutrophil elastase activity.

In the children with bronchiolitis compared with control infants, elevated levels of IL-8 (median (range) $1.53(0-153)$ versus $\left.0(0-5.6) \mathrm{ng} \cdot \mathrm{mL}^{-1}\right)$ HNE (136 (32-694) versus $\left.14(0-516) \mathrm{ng} \cdot \mathrm{mL}^{-1}\right)$ and elastase activity $\left(4(1-220)\right.$ versus $\left.1(0-339) \mathrm{mU} \cdot \mathrm{mL}^{-1}\right)$ were found.

These results indicate that interleukin- 8 is released in the upper respiratory tract in response to respiratory syncytial virus infection and suggest that polymorphonuclear neutrophil products are playing an important role in the inflammatory response to respiratory syncytial virus infection in infants with acute bronchiolitis. This contrasts with the predominantly eosinophilic response evident in atopic upper and lower respiratory tract disease.

Eur Respir J 1999; 14: 139-143.
*Paediatric Respiratory Unit, Sheffield Children's Hospital, Sheffield, UK. ${ }^{+}$Section of Respiratory Medicine, University of Wales College of Medicine, Llandough Hospital, Cardiff, UK.

Correspondence: M.L. Everard

Dept of Respiratory Medicine

Sheffield Children's Hospital

Western Bank

Sheffield S10 2TH

UK

Fax: 441142730522

Keywords: Bronchiolitis interleukin-8

neutrophil elastase

respiratory syncytial virus

Received: June 171998

Accepted after revision February 11999
Respiratory syncytial virus (RSV) bronchiolitis is the commonest form of lower respiratory tract disease in infancy [1-4]. Despite intensive efforts over the past 30 yrs, the nature of the inflammatory process within the respiratory tract of infants with RSV bronchiolitis has not been clearly characterized. Many have speculated that there is a distinct immunopathological process present in the airways of infants with RSV bronchiolitis. However, the same clinical picture can be induced by a number of respiratory viruses and there is no evidence from the human host that a specific immunopathology does lead to the development of acute bronchiolitis in some infants infected with the virus. Previous work from the authors' group suggests that an intense neutrophil influx characterizes the inflammatory process in the airways of these patients and that the inflammatory response is similar in nature to that observed in viral respiratory tract infections differing only in its intensity and distribution.

The initial suggestion that there may be a specific immunopathology was made $>25$ yrs ago and was based on the observations that: the majority of infants are infected with the virus during the first winter after their birth, but only $0.5-2 \%$ of such infants develop bronchiolitis severe enough to require hospitalization; the most severely affected individuals with RSV bronchiolitis are generally $<6$ months of age; and the administration of a formalin inactivated vaccine resulted in excess morbidity in immunized infants [1-4]. A number of hypotheses have been proposed since then and these have included the suggestion that the immunopathology can be attributed to an RSV specific immunoglobulin (Ig)E response; immune complex disease; excessive cytotoxic CD8 activity; excessive CD4 activity; and the suggestion that an aberrant T-helper 2 response with excessive eosinophil influx is responsible [1-5]. Many of these have been supported by experimental evidence using rodents as animal models. However, these animals do not develop bronchiolitis or other significant clinical respiratory symptoms [1] and it is far from clear whether any of these results bear any resemblance to the events occurring in the humans who are the only natural host for the virus. The response in the rodent is determined by the choice of rodent. There is little direct evidence from studies in humans to support any of these proposed mechanisms.

The authors' have recently demonstrated that neutrophils are present in large numbers in the airways of infants with RSV bronchiolitis and represent $>76 \%$ of all cells in lavage fluid obtained from both the upper and lower respiratory tract of these infants [6]. As a result, it is hypothesized that this neutrophil response was likely to 
be contributing significantly to the airways obstruction through the release of inflammatory mediators that would contribute to airways oedema, mucus secretion and excessive airways fluid.

In vitro studies have shown that $\mathrm{RSV}$ infection of airways alveolar macrophages [7] and epithelial cells [811] stimulates these cells to release interleukin (IL)-8, a potent neutrophil chemotactic factor. Furthermore, infectious and inactivated RSV particles as well as RSVantibody complexes stimulate neutrophils to secrete IL-8 in vitro [11]. One group has reported elevated IL-8 levels in serum of infants with RSV bronchiolitis [12]. The effects of RSV infection on neutrophil function during infection is unclear. In one study it was observed that phagocytosis of RSV appeared to inhibit oxygen radical production by neutrophils in response to various stimuli [11], although a second study suggested that phagocytosis of RSV complexes enhanced oxygen radical production and arachadonic acid metabolism [13].

The purpose of this study was to determine whether IL-8 is produced in vivo within the airways of infants infected with RSV and to try to clarify whether neutrophils are contributing to the inflammatory process through the release of inflammatory products such as human neutrophil elastase (HNE).

\section{Patients and methods}

Samples of airways fluid were obtained by nasal lavage from 47 infants. Twenty-seven infants with acute bronchiolitis were recruited from patients admitted to the Sheffield Children's Hospital during the 1995-1996 winter epidemic and 20 infant control subjects were recruited from a cohort participating in a community-based vaccine study. These were seasonally matched in that they were recruited during the same epidemic period. Infants were characterized clinically by coryza, cough, hyperinflation, tachypnoea and widespread crepitation on auscultation with or without wheeze [3].

Approval for this study was granted by the South Sheffield Ethics Committee. Informed consent was obtained from the parents of all the subjects.

\section{Subjects}

All the 27 inpatients were confirmed RSV-positive by indirect immunofluorescence on nasopharyngeal aspirates before they were recruited to the study. Their ages ranged 2-38 weeks (median 9 weeks). Three infants had been born before 37 weeks gestation, two of whom were born before 34 weeks. All were post-term at entry to the study.

The age range of the control group was 20-32 weeks with a median age of 25 weeks. All had been born at 37 weeks of gestation or later.

None of the infants in either group had been ventilated in the neonatal period and none had pre-existing cardiac or respiratory disease.

\section{Nasal washings}

Nasal lavage was performed with the infant held in a supine position. Two millilitres of phosphate-buffered saline (PBS) were gently instilled into each nostril. This was simultaneously suctioned back from the anterior nares using a modified soft rubber 8 FG Argyle catheter (Sherwood Medical, Tullamore, Ireland). The catheter was attached to a standard mucus trap or suction collector (Wallace Ltd, Colchester, Essex, UK), connected to suction using a pressure $2.7-6.7 \mathrm{kPa}(20-50 \mathrm{mmHg})$. Samples were held on ice until arrival in the laboratory where the lavage fluid was centrifuged at $300 \times g$ for $5 \mathrm{~min}$. The supernatant was separated from the pelleted cellular debris and then stored separately at $-70^{\circ} \mathrm{C}$.

\section{Immunological determination of total neutrophil elastase}

Neutrophil elastase was measured by an enzyme-linked immunosorbent assay (ELISA). Plates were coated with goat anti-HNE antibody (at a dilution of 1:1,000) overnight at $4{ }^{\circ} \mathrm{C}$. The rest of the assay was completed at room temperature. Plates were washed in $10 \mathrm{mM}$ phosphate buffer, $137 \mathrm{mM} \mathrm{NaCl}, 0.1 \%$ bovine serum albumin (BSA), $0.1 \%$ Tween 20, $\mathrm{pH} 7.4$, and then blocked with PBS containing $1 \%$ BSA and washed again. Samples at a dilution of 1:10-1:100 and standard in the range of $0.1-500$ $\mathrm{ng} \cdot \mathrm{mL}^{-1}$ elastase were added to the wells. $\alpha_{1}$-Antitrypsin was present in the standard and sample diluent at 10 $\mu \mathrm{g} \cdot \mathrm{mL}^{-1}$ in PBS $/ 0.1 \% \mathrm{BSA}$. This is sufficient to saturate all the NE in the range of the standard curve. Plates were gently shaken for $2 \mathrm{~h}$, washed and goat anti-human $\alpha_{1}$ antitrypsin-alkaline phosphate conjugate added to the wells. After $1.5 \mathrm{~h}$ shaking, plates were washed and phosphate substrate ( $p$-nitrophenyl phosphate disodium hexahydrate, $1 \mathrm{mg} \cdot \mathrm{mL}^{-1}$; Sigma 104 , Sigma, Poole, UK) in $10 \%$ diethanolamine $\mathrm{pH} 9.8$ was added. After $30 \mathrm{~min}$, plates were read at $405 \mathrm{~nm}$ (reference $490 \mathrm{~nm}$ ), and the NE levels in the samples determined from the standard curve. Intra- and inter-assay variation was 12 and 5\%, respectively. The lower level of detection was $0.01 \mathrm{ng} \cdot \mathrm{mL}^{-1}$.

\section{Determination of neutrophil elastase activity}

Samples were analysed for elastase activity using the chromogenic substrate $N$-methoxysuccinyl-ala-ala-proval- $p$-nitroanilide (Sigma) in a Tris- $\mathrm{NaCl}$ buffer $(\mathrm{pH} 7.5)$ at $25^{\circ} \mathrm{C}$. Elastase activity was determined by the increase in absorbance at $410 \mathrm{~nm}$, expressed as $\mathrm{U} \cdot \mathrm{mL}^{-1}$ plotted against a known standard. The lower level of detection was 0.05 $\mathrm{mU} \cdot \mathrm{mL}^{-1}$.

\section{Interleukin-8 assay}

An established in-house assay was used. The monoclonal capture antibody $\left(10 \mu \mathrm{g} \cdot \mathrm{mL}^{-1} \mathrm{TY} 1, \mathrm{HB} 9647\right.$, a gift from E.J. Leonard, Sandoz, Vienna, Austria) was used to coat high binding poly-vinyl chloride (PVC) plates (Corning Costar, High Wycombe, UK) in carbonate/bicarbonate buffer ( $\mathrm{pH} 9.6)$ for $18 \mathrm{~h}$ at $4{ }^{\circ} \mathrm{C}$, washed and blocked for $1 \mathrm{~h}$. Plasma samples and standards $\left(0-100 \mathrm{ng} \cdot \mathrm{mL}^{-1}\right.$ of recombinant IL-8 (rIL-8) (a gift from C. Cashin, Roche Research Centre, UK) were added and incubated for $3 \mathrm{~h}$. Wells were washed and incubated with polyclonal sheep serum (a gift from A. Mire-Sluis, National Institute for Biological Standards Control, UK) conjugated to biotin (Pierce \& Warriner, Chester, UK) (1:500) for $1 \mathrm{~h}$. Wells were washed and incubated with avidin/biotin conjugate 
(Pierce \& Warriner) for $30 \mathrm{~min}$. After washing substrate solution containing Tris-HG (Sigma), $p$-nitrophenylphosphate ( $p$-NPP; Sigma), $\mathrm{MgCl}_{2}$ (BDH-Merck, Poole, UK) and $\mathrm{CaCl}_{2}(\mathrm{BDH}-\mathrm{Merck})$ was added and plates read at $414 \mathrm{~nm}$.

Tris buffer ( $\mathrm{pH} 7.5$ ) with $0.05 \%$ Tween-20 (Sigma) and $0.1 \%$ BSA (Advanced Protein Products, Brierly Hill, UK) was used for all washes. Detection antibody, standards and blocking steps were diluted with Tris buffer ( $\mathrm{pH} 7.5)$ containing 2\% BSA. Incubations and blocking were at room temperature. All samples were assayed in duplicate and IL8 concentrations calculated from a concurrent standard curve. The lower limit of detection was $2 \times$ optical density of wells which did not contain rIL-8 and was $205 \mathrm{pg} \cdot \mathrm{mL}^{-1}$ $\left(0 \mathrm{pg} \cdot \mathrm{mL}^{-1}\right.$ represents values below the lower level of detection, i.e. $<205 \mathrm{pg} \cdot \mathrm{mL}^{-1}$ ).

\section{Statistical analysis}

The significance of apparent differences between the study group and the control group were assessed using a two-group, two-tailed Mann-Whitney nonparametric test for non-normally distributed data.

\section{Results}

The concentrations of IL-8, HNE and NE activity in the two groups are shown in figure 1.

A history of upper respiratory tract infection was sought from parents of all the control infants at the time of the nasal lavage. Four infants had symptoms of upper respiratory tract infection with nasal discharge coryza and cough. These are shown in figure 1 . The virus responsible for their symptoms was not known.

IL-8 was detected in all but one of the study group (median (range) 1,530 $\left.(0-111,000) \mathrm{pg} \cdot \mathrm{mL}^{-1}\right)$. By contrast IL-8 could only be detected in seven of 20 control subjects, three of whom had symptoms (median (range) 0 (0$\left.56,000) \mathrm{pg} \cdot \mathrm{mL}^{-1}\right)$. The differences were highly significant $(\mathrm{p}<0.0001)$.

The total HNE in the study group (median (range) 136 $\left.(32-694) \mathrm{ng} \cdot \mathrm{mL}^{-1}\right)$ was again significantly higher in the control group (median (range) $\left.14(0-516) \mathrm{ng} \cdot \mathrm{mL}^{-1}\right)(\mathrm{p}<$ $0.0002)$. NE activity was also significantly elevated in bronchiolitics (median (range) $4(1-220) \mathrm{mU} \cdot \mathrm{mL}^{-1}$ ) compared with control subjects (median (range) $1(0-339) \mathrm{U} \cdot \mathrm{mL}^{-1}$ ) $(\mathrm{p} \leq 0.0028)$. The highest elastase activity was measured in a symptomatic control subject who also had markedly elevated concentrations of total elastase and IL-8 in nasal washings. If those control subjects with upper respiratory tract infections were excluded from the analysis the differences were more significant, with that for free elastase being $\mathrm{p}<0.0005$.

\section{Discussion}

These results indicate that IL-8 is released in vivo within the upper respiratory tract of infants with RSV bronchiolitis and that this is likely to play a major role in promoting the intense inflammatory process evident within the airways of infants with acute bronchiolitis through recruitment of neutrophils. The authors have previously shown that these cells are present in very large numbers in
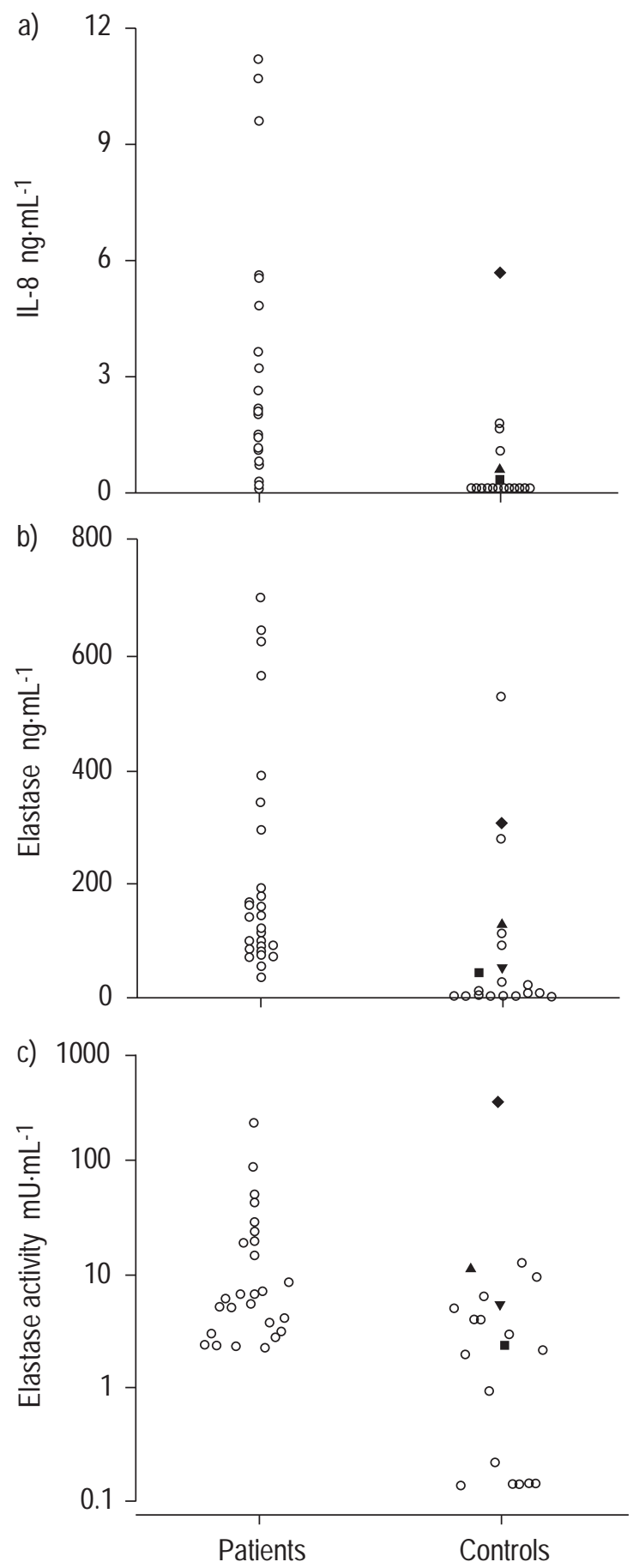

Fig. 1. - Concentrations of interleukin (IL)-8 (a), total human neutrophil elastase (b) and elastase activity (c) in nasal lavage samples from infants with respiratory syncytial virus bronchiolitis and control subjects. Closed symbols amongst control subjects were four infants with evidence of upper respiratory tract symptoms.

the airways of infants with RSV bronchiolitis [6] and the results from this study indicate that they make a major contribution to the inflammatory process through release of products such as NE. The release of inflammatory mediators such as HNE and oxygen radicals [13] by neutrophils is likely to contribute to the increased quantities of mucus and airways fluid characteristic of the disease, and hence they are likely to be playing a major role in the 
causation of lower airways obstruction. Furthermore, products such as free NE may have important effects on the developing lungs through mechanisms such as stimulating mucus and goblet cell hyperplasia or creating structural changes that predispose these infants to further problems. Consequently, these cells may make a significant contribution to the considerable respiratory morbidity experienced by patients in the years following acute RSV bronchiolitis [1-4, 14].

It is now recognized that neutrophils play an important role in viral respiratory tract infections. The importance of their role in eliminating viral infection is unclear and indeed they may have little or no effect in limiting viral replication. However, there is evidence that they play an important role in the causation of symptoms during respiratory viral infections. Studies have demonstrated neutrophils in nasal lavage and mucosal biopsy samples from individuals with upper respiratory tract infections [15-17]. More compelling is the observation that adult volunteers experimentally infected with rhinovirus appear not to develop symptoms, even in the presence of viral replication, unless there is an influx of neutrophils [18]. A recent study has demonstrated elevated IL-8 levels in the nasal secretions from children with asthma obtained during viral respiratory tract infections. They also noted that levels of the neutrophil product myeloperoxidase (MPO) correlated with the severity of upper respiratory tract symptoms [19], again indicating that neutrophils play a role in the causation of respiratory tract symptoms during viral infections.

In the present study, samples were obtained from the respiratory tract of infants with acute bronchiolitis using a nasal lavage technique. Previous lavage studies have shown a similarity in profiles of samples obtained from the upper and lower airways in a range of settings [20-23] although this technique cannot be used in all conditions. For example, there appears to be little correlation between findings in lavage fluid obtained from the upper and lower respiratory tract in cystic fibrosis [24] and neonatal respiratory distress syndrome (A. Gibson, Jessop Maternity Hospital, Sheffield, UK, personal communication). However, previous studies by the authors found no difference in the pattern of inflammation noted in samples from the lower or upper airways of infants ventilated for acute RSV bronchiolitis $[6,25]$ indicating that findings obtained in samples from the upper airway do reflect events within the lower airways of infants with RSV bronchiolitis. Currently there is no evidence that the inflammatory process in the lungs of those with acute RSV bronchiolitis differs significantly to that in the upper airway or indeed that the process differs in any respect other than distribution within the airways from those infants with RSV upper respiratory tract infections alone. It is believed that this technique provides useful information that is relevant to the process occurring within the lungs of infants with bronchiolitis. Others have used this approach in infants infected with RSV [26-27].

Much is still to be learned about the effects of the RSV on the host response. The receptors involved in viral attachment have still not been identified and how the virus prevents the host from establishing long-lasting effective immunity has not been fully explained, although many immunosuppresive effects have been identified [1-4]. As noted above, the virus is not unique in its ability to induce
IL-8 production by infected epithelial cells and indeed neutrophil influx is a feature of viral respiratory tract infections. For respiratory viruses, the induction of neutrophilia within the airways is more advantageous to the virus than the host. Neutrophil products will stimulate the host to secrete mucus as well as induce sneezing and coughing, all of which are important in transmission of the virus. The annual influx of infants with bronchiolitis attributable to RSV epidemics may simply reflect the ability of the virus to prevent mothers developing adequate immunity resulting in very high infection rates amongst infants during their first winter. The infants seen in hospitals represent a small proportion of those infected. It is unlikely that the nature of the inflammatory response in the airways of infants with bronchiolits is any different to that seen in other infants with RSV upper respiratory tract infections alone. The extent of the process is likely to be influenced by factors such as infecting dose and titres of passively acquired neutralizing titres. The well documented immunosuppressive properties of the virus [1-4] results in low passively acquired protective neutralizing antibody levels in many infants and is likely to contribute to the extension of the inflammatory process from the upper to lower airways. A unique immunopathological mechanism is not required to explain these epidemics that place such strains on paediatric services.

This study has shown that interleukin-8 levels were significantly elevated in nasal secretions of infants with acute bronchiolitis as compared with control subjects. The study has also demonstrated elevated levels of neutrophil elastase and elastase activity in the respiratory tract in these patients. These results indicate that neutrophils are contributing significantly to the airways inflammation of infants with acute bronchiolitis in contrast to the predominantly eosinophilic response in atopic upper and lower respiratory disease.

\section{References}

1. McIntosh K, Chanock RM. Respiratory syncytial virus. In: Fields BM, Knipe DM, eds. Fields Virology. 2nd Edn. New York, Raven Press, 1990; pp. 1045-1072.

2. Ruuskanen O, Ogra PL. Respiratory syncytial virus. Current Prob Pediatr 1993; 23: 50-79.

3. Everard ML, Milner AD. The respiratory syncytial virus and its role in acute bronchiolitis. Eur J Pediatr 1992; 151: 638-651.

4. Everard ML. Respiratory syncytial virus bronchiolitis and pneumonia. In: Taussig L, Landau L, eds. Textbook of Paediatric Respiratory Medicine. St. Louis, Mosby, 1998; pp. 580-594.

5. Openshaw PJ. Immunity and immunopathology to respiratory syncytial virus: the mouse model. $\mathrm{Am} \mathrm{J}$ Respir Crit Care Med 1995; 152: S46-S52.

6. Everard ML, Swarbrick A, Wrightham M, et al. Analysis of cells obtained by bronchial lavage of infants with respiratory syncytial virus infection. Arch Dis Child 1994; 71: 428-432.

7. Becker S, Quay J, Soukup J. Cytokine (tumor necrosis factor, IL-6, IL-8) production by respiratory syncytial virus-infected human alveolar macrophages. J Immunol 1991; 147: 4307-4312.

8. Becker S, Koren HS, Henke DC. Interleukin-8 expression in normal nasal epithelium and its modulation by 
infection with respiratory syncytial virus and cytokines tumour necrosis factor, interleukin-1 and interleukin-6. Am J Respir Cell Mol Biol 1993; 8: 20-27.

9. Arnold R, Humbert B, Werchau H, Gallati H, Konig W. Interleukin-8, interleukin-6, and soluble tumour necrosis factor receptor type 1 release from a human pulmonary epithelial cell line (A549) exposed to respiratory syncytial virus. Immunol 1994; 82: 126-133.

10. Fiedler MA, Wernke-Dollries K, Stark JM. Respiratory syncytial virus increases IL-8 gene expression and protein release in A549 cells. Am J Physiol 1995; 269: L865-872.

11. Arnold R, Werner F, Humbert B, Werchau H, Konig W. Effect of respiratory syncytial virus-antibody complexes on cytokine (IL-8, IL-6, TNF- $\alpha$ ) release and respiratory burst in human granulocytes. Immunol 1994; 82: 184 191.

12. Biswas S, Friedland JS, Remick DG, Davies EG, Sharland M. Elevated plasma interleukin 8 in respiratory syncytial virus bronchiolitis (letter). Pediatr Infect Dis $J$ 1995; 14: 919.

13. Faden H, Kaul TN, Ogra PL. Activation of oxidative and arachidonic acid metabolism in neutrophils by respiratory syncytial virus antibody complexes: possible role in disease. J Infect Dis 1983; 148: 110-116.

14. Noble V, Murray M, Webb MSC, Alexander J, Swarbrick AS, Milner AD. Respiratory status and allergy nine to 10 years after acute bronchiolitis. Arch Dis Child 1997; 76: 315-319.

15. Levaandowski RA, Weaver CW, Jackson GG. Nasal secretion leukocyte populations determined by flow cytometry during acute rhinovirus infection. $J$ Med Virol 1988; 25: 423-432.

16. Naclerio RM, Proud D, Lichenstein LM, et al. Kinins are generated in experimental rhinovirus colds. $J$ Infect Dis 1988; 157: 133-145.

17. Winther B, Farr B, Turner RB, et al. Histopathologic examination and enumeration of polymorphonuelear leukocytes in the nasal mucosa during experimental rhino- virus colds. Acta Otolaryngologica Suppl (Stockh) 1984; 413: $19-24$.

18. Turner RB. The role of neutrophils in the pathogenesis of rhinovirus infections. Pediatr Infect Dis J 1990; 9: 832835.

19. Teran LM, Johnston SL, Schroder J-M, Church MK, Holgate ST. Role of nasal interleukin-8 in neutrophil recruitment and activation in children with virus induced asthma. Am J Respir Crit Care Med 1997; 155: 13621366.

20. Noah TL, Henderson FW, Henry MM, Peden DB, Develin RB. Nasal lavage cytokines in normal, allergic and asthmatic school-age children. Am J Respir Crit Care Med 1995; 152: 1290-1296.

21. Persson CGA, Svensson C, Grieff L, et al. The use of the nose to study the inflammatory response of the respiratory tract. Thorax 1992; 47: 993-1000.

22. Poulter LWA, Norris C, Power A, et al. T cell dominated inflammatory reactions in the bronchioles of asymptomatics are also present in the nasal mucosa. Postgrad Med $J$ 1991; 67: 747-753.

23. Ferguson AC, Whitelaw M, Brown H. Correlation of bronchial eosinophil and mast cell activation with bronchial hyperresponsiveness in children with asthma. $J$ Allergy Clin Immunol 1992; 90: 609-613.

24. Noah T, Black HR, Chong P-W, Wood R, Leigh MW. Nasal and bronchial lavage fluid cytokines in early cystic fibrosis. J Infect Dis 1997; 115: 638-639.

25. Everard ML, Fox G, Walls A, et al. Tryptase and IgE concentrations in the respiratory tract of infants with acute bronchiolitis. Arch Dis Child 1995; 72: 64-69.

26. Colocho Zelaya EA, Orvell C, Strannegard O. Eosinophil cationic protein in nasopharyngeal secretions and serum of infants infected with respiratory syncytial virus. Pediatr Allergy Immunol 1994; 5: 100-106.

27. Garofalo R, Kimpen JL, Welliver RC, Ogra PL. Eosinophil degranulation in the respiratory tract during naturally aquired respiatory syncytial virus infection. $J$ Pediatr 1992; 120: 28-32. 